\title{
Effect of Nitrogen and Sulphur Fertilization on Chlorophyll Content in Winter Wheat
}

\author{
*Ilze Skudra ${ }^{1,2}$, Antons Ruza ${ }^{1}$ \\ ${ }^{1}$ Latvia University of Agriculture, Faculty of Agriculture, Institute of Agrobiotechnology, \\ Lielā street 2, Jelgava, LV-3001, Latvia \\ ${ }^{2}$ Latvian Rural Advisory and Training centre, Ltd., Rīgas Street 34, Ozolnieki, \\ Ozolnieki parish, Ozolnieki district, LV-3018, Latvia
}

\begin{abstract}
Nitrogen management strategy in plant growth period based on chlorophyll content evaluation in plant can improve nitrogen usage efficiency and reduce environmental contamination. This study is aimed to determine the impact of different nitrogen and sulphur fertilizer rates on dynamics of chlorophyll content in winter wheat during vegetative growth and to determine the relationship between nitrogen and chlorophyll content and grain yield of winter wheat. Field trial involving a winter wheat (Triticum aestivum L.) variety 'Kranich' was conducted at the LUA Research and Study Farm Vecauce during a three-year period (20122015). The treatments were $0,85,153,175+\mathrm{S} 21,175$ (in 2015), $187 \mathrm{~N} \mathrm{~kg} \mathrm{ha}^{-1}$ and different nitrogen norms according to chlorophyll meter Yara N-tester (Konica Minolta Ltd.) data: 180, 150, $205 \mathrm{~N} \mathrm{~kg} \mathrm{ha}^{-1}$ depending on the year. The results of the trial show that the maximum chlorophyll content in different plant parts was observed at the end of flowering stage. The chlorophyll content depended on the level of mineral fertilisation. The highest chlorophyll content in leaves, stems and ears was obtained by using additional sulphur in two trial years. Usage of chlorophyll meter Yara N-tester obtained the highest chlorophyll content in all analyzed plant parts in one trial year. Chlorophyll content was significantly dependant on plant growth stage in stems in all trial years, in leaves in two trial years, and in ears in one year. Nitrogen fertilization significantly affected chlorophyll content in leaves and stems in one trial year. Close positive correlation was observed between grain yield and wheat plant chlorophyll content and average nitrogen concentration at the end of flowering stage in all three trial years.
\end{abstract}

Key words: nutrient, photosynthetic pigments, development stages, Yara N-tester.

\section{Introduction}

It is very important to optimize efficient usage of nitrogen fertilizer in order to provide a sustainable cereal production and maintenance of good quality ground and surface waters. Cereals have different demands for nitrogen at different stages of growth (Akhter et al., 2016; Bojovič \& Markovič, 2009; Tarnavičiene et al., 2008). Chlorophyll content is the appropriate parameter for the evaluation of nitrogen uptake (Shadchina \& Dmitrieva, 1995). Determining the estimate of the nitrogen status of the plant may be done with the help of leaf diagnostics which is based on the relationship between nitrogen concentration and chlorophyll content in the plant leaves (Stramkale et al., 2008, Castelli, Contillo, \& Miceli, 1996).
Chlorophyll content showed a high correlation with the nitrogen concentration in the wheat plant (Schlichting et al., 2015, Akhter et al., 2016) and within plant leaves (Shadchina \& Dmitrieva, 1995). Therefore, the leaf nitrogen fast determination is particularly useful in plant growth phases (for example - stem elongation), where responses to fertilization depend on the timing of the intervention (Castelli, Contillo, \& Miceli, 1996).

Nitrogen concentration in the plant is traditionally diagnosed with a plant tissue analyses, but those are costly, time consuming and often unavailable to users. Several studies (Akhter et al., 2016, Sclichting et al., 2015, Živčak et al., 2014) have reported on faster and non-destructive new tools which characterize

\footnotetext{
* Corresponding Author's email: 
nitrogen status in plant. Optical properties of leaf pigments (chlorophyll and polyphenols) have been used as wheat plant nitrogen status indicators (Foxa, Piekieleka, \& Macneala, 1994). The chlorophyll meter Yara N-tester (Konica Minolta Ltd.) can serve as a diagnostic tool for this purpose. It is simple, nondestructive, portable device used for determining chlorophyll content. Chlorophyll meter readings have been positively correlated with destructive chlorophyll measurements in wheat (Akhter et al., 2016) and have been a useful indicator for nitrogen top-dressing determination during plant vegetative period.

Leaf chlorophyll content in wheat varies from 0.5 to $3.0 \mathrm{mg} \mathrm{g}^{-1}$ of fresh matter according to data obtained by Serbia scientists (Bojovič \& Stojanovič, 2005), but Russian scientists (Marinkina \& Marx, 2014) obtained from 2 to $8 \mathrm{mg} \mathrm{g}^{-1}$ of leaf dry matter. These values vary along with the plant growth and development. In most cases, the highest value content of pigments in wheat green leaves was observed at the end of flowering phase (Bojovič \& Stojanovič, 2005, Tranavičiene et al., 2008), but Priadkina et al. (2014) research in Ukraine Kiev region showed that the greatest chlorophyll content in plants occurred in the phase of milk development. Reduced chlorophyll content is connected with mineral nutrient deficiency. The content of chlorophyll depends on plant provision with nitrogen (Bojovič, \& Markovič, 2009, Karele, 2001). Several studies (Jarvan, Edesi, \& Adamson, 2012, Kulhanek et al., 2014) indicated that the effect of applied sulphur on the wheat yield and grain quality is closely related to nitrogen supply. Sulphur fertilizer increased nitrogen use efficiency. Research in Argentina (Salvagiotti et al., 2009) has shown that sulphur fertilization apparently increased recovery efficiency by increasing the crop's ability to take up applied nitrogen, possibly by increasing soil exploration by the roots, but it did not increase the grain nitrogen concentration. The management of nitrogen and sulphur is important for reducing the potential pollution of residual soil nitrate by increasing nitrogen recovery from the soil and sustaining high nitrogen use efficiency.

The aim of this study was to analyse influence of different nitrogen and sulphur fertilizer rates on chlorophyll content dynamics in winter wheat during the growth period by improving nitrogen use efficiency and to determine the relationship between nitrogen concentration and chlorophyll content and grain yield of winter wheat.

\section{Materials and Methods}

Site and soil properties. A field experiment with winter wheat (Triticum aestivum L.) cultivar 'Kranich' was set up at the Research and Study farm "Vecauce" (latitude: N 56 47', longitude: E $22^{\circ}$ $85^{\prime}$ ) of Latvia University of Agriculture during the period from 2012/2013 to 2014/2015. The soil (by World Reference Base for Soil Resources) at the site was Endostagnic Phaeozem (Loamic), loam. Soil agro-chemical parameters were slightly different depending on a year (Table 1).

Treatment and agronomic management. Sowing rate for winter wheat cultivar 'Kranich' was 450 seeds per $\mathrm{m}^{2}$. Field trial plots were arranged in a randomized block design with four replications. Pre - crop in trial sites were winter rape in 2013 and 2014, spring wheat in 2015. The compound fertilizer was applied in autumn. $300 \mathrm{~kg}$ of NPK 5-15-25 were used for fertilizing in 2012 containing $\mathrm{N}-15, \mathrm{P}-20, \mathrm{~K}-62$ $\mathrm{kg} \mathrm{ha}^{-1}$, the same amount of NPK 6-26-30 containing $\mathrm{N}-18, \mathrm{P}-34, \mathrm{~K}-75 \mathrm{~kg} \mathrm{ha}^{-1}$ was applied in 2013 , but $180 \mathrm{~kg}$ of the same fertilizer were used in 2014 containing $\mathrm{N}-11, \mathrm{P}-20, \mathrm{~K}-45 \mathrm{~kg} \mathrm{ha}^{-1}$. Tested six nitrogen fertilizer rates applied as $\mathrm{NH}_{4} \mathrm{NO}_{3}: 85 \mathrm{~kg} \mathrm{ha}^{-1}$ $\mathrm{N}, 153 \mathrm{~kg} \mathrm{ha}^{-1} \mathrm{~N}$ in two splits $(85+68), 175 \mathrm{~kg} \mathrm{ha}^{-1} \mathrm{~N}$ in three splits $(85+60+30)$ : the first dose as $\mathrm{NH}_{4} \mathrm{NO}_{3}$, but the second and third as $\left(\mathrm{NH}_{4}\right)_{2} \mathrm{SO}_{4}$, in $2015-175$ $\mathrm{kg} \mathrm{ha}^{-1} \mathrm{~N}$ in three splits $(85+60+30)$ all doses as

Table 1

Soil agro-chemical parameters at trial site in 2013-2015

\begin{tabular}{lccc}
\hline \multicolumn{1}{c}{ Parameter } & \multicolumn{2}{c}{ Year } \\
\cline { 2 - 4 } & 2013 & 2014 & 2015 \\
\hline Organic matter, g kg-1 of soil (by Tiurin method) & 23 & 17 & 25 \\
Soil exchange reaction pH KCl & 6.6 & 7.2 & 6.7 \\
Plant available P, mg kg-1 (by Egner - Rheem method) & 122 & 50 & 153 \\
Plant available K, mg kg-1 (by Egner - Rheem method) & 118 & 150 & 144 \\
Plant available S, $\mathrm{mg} \mathrm{kg}^{-1}$ (in extractant - 1 molar KCl & 0.2 & 1.3 & 0.2 \\
solution) & & & \\
\hline
\end{tabular}


$\mathrm{NH}_{4} \mathrm{NO}_{3}, 187 \mathrm{~kg} \mathrm{ha}^{-1} \mathrm{~N}$ in three splits $(85+68+34)$, and $\mathrm{N}$ application based upon chlorophyll meter Yara N-tester proposed by Inada K. (1963), developed by Konica Minolta Ltd., data: in $2013-180 \mathrm{~kg} \mathrm{ha}^{-1} \mathrm{~N}$ $(85+50+45)$, in $2014-150 \mathrm{~kg} \mathrm{ha}^{-1} \mathrm{~N}(85+50+15)$, in $2015-205 \mathrm{~kg} \mathrm{ha}^{-1} \mathrm{~N}(85+50+70)$. Split nitrogen dressing was applied in spring at the beginning of wheat regrowth $(\mathrm{BBCH} 25-27)$ for the first time, at the stem elongation $(\mathrm{BBCH} 30-32)$ for the second time and at the beginning of heading (BBCH 49-51) for the third time. Plant protection actions were made to prevent suboptimal plant growth conditions due to weed infestation and diseases. Crops were harvested at the ripening stage $(\mathrm{BBCH} 88-92)$ on August 6, 2013, August 8, 2014 and August 13, 2015. The grain yield was adjusted to $14 \%$ moisture content.

Data collection. Hand held chlorophyll meter Yara N-tester is based on the Minolta SPAD-502 which measures light transmitted from the plant leaf at 650 and $940 \mathrm{~nm}$ wavelengths. The leaf greenness is positively related to leaf chlorophyll content, which has a close correlation with leaf nitrogen concentration (Akhter et al., 2016; Schlichting et al., 2015). The chlorophyll meter was used for non-destructive chlorophyll determination. At least 30 fully developed upper leaves were chosen to measure the chlorophyll content. Yara N-tester measurements in winter wheat were done during growth stages $\mathrm{BBCH} 37$ to 51 in order to recommend necessary amount of nitrogen. Readings above 700 on Yara N-tester suggests the crop has sufficient nitrogen, a reading below 650 suggests the crop is likely to be deficient. Readings between 650 and 700 require a judgement based on recent nitrogen applications, previous fertilizer, current weather and growing conditions and whether the 3 digit value has increased or decreased since the previous reading.

Photosynthetic pigment content analysis was performed in growth stages $\mathrm{BBCH} 32,51$, 69. Photosyntetic pigment (chlorophyll a and b) content in fresh matter of leaves, stems, and ears was determined spectrophotometrically in dimetylsulphoxide extract. Fresh plant tissues with dimetylsulfoxide were incubated in a glass tube at $65{ }^{\circ} \mathrm{C}$ at least 60 min (Richardson, Duigan, \& Berlyn, 2002). Spectrophotometer - Lambda 25 (PerkinElmer, USA) is used at two wavelengths 665 and $649 \mathrm{~nm}$ for maximum absorption of chlorophyll a and $b$, respectively. Chlorophyll a and chlorophyll b were obtained based on the equations by Wellburn A.R. (1994). Nitrogen concentration in leaves, stems and ears was analysed by LVS EN ISO 5983-2: 2009 method, \%. Biochemical analyses were done in two replications.

Statistical analysis. Analysis of variance was performed using the ANOVA procedures. Statistical significance was evaluated at the $\mathrm{P} \leq 0.05$ and $\mathrm{P} \leq 0.01$ probability levels. Correlation analyses were used for processing the experimental data and calculating indices by using Excel data Analyses tool pack.

Weather conditions. The weather conditions varied throughout the experimental years. In 2013 and 2015 wheat overwintered successfully, but in 2014 some of winter wheat did not survive due to unfavourable wintering conditions. According to the records of Vecauce meteorological station, the average air temperature in 2013-2015 and long-term temperatures are summarized in Figure 1. In 2013,

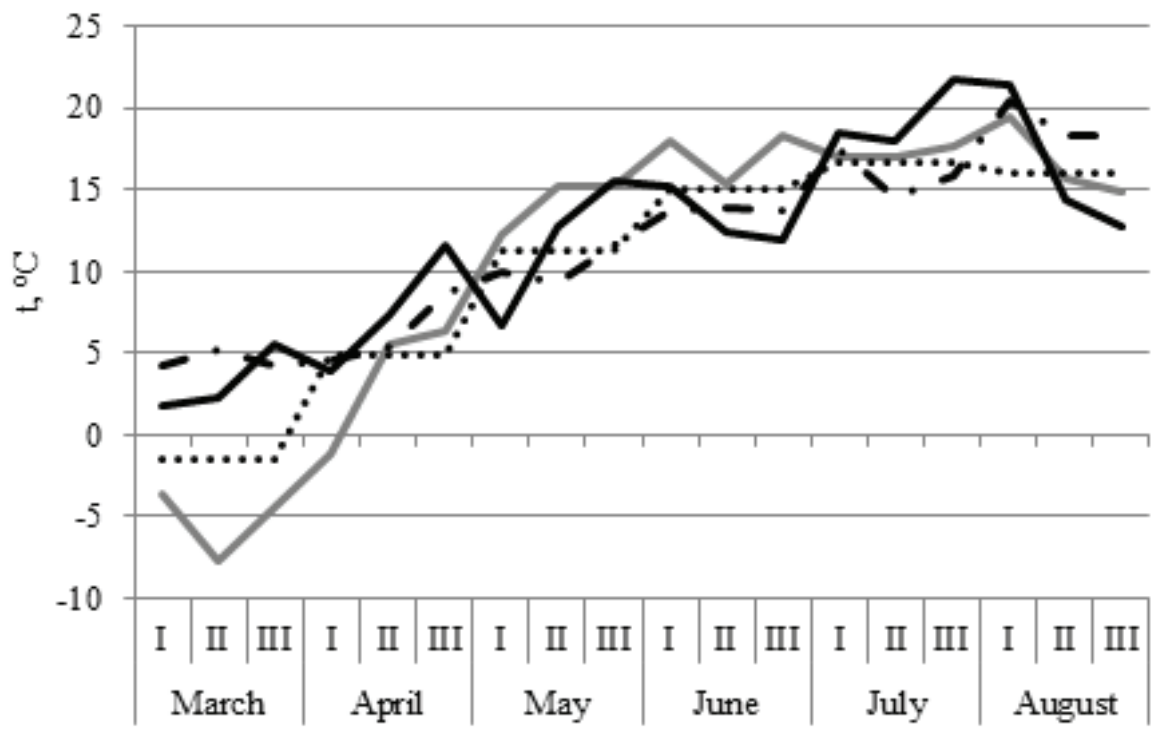

Figure 1. Mean temperatures, Vecauce, 2013-2015 vegetation periods, ${ }^{\circ} \mathrm{C}$, the records of Vecauce meteorological station $\left(--2013,--2014, \ldots{ }_{-}-2015, \ldots . .-\right.$ long term average, I, II, III - ten day period). 


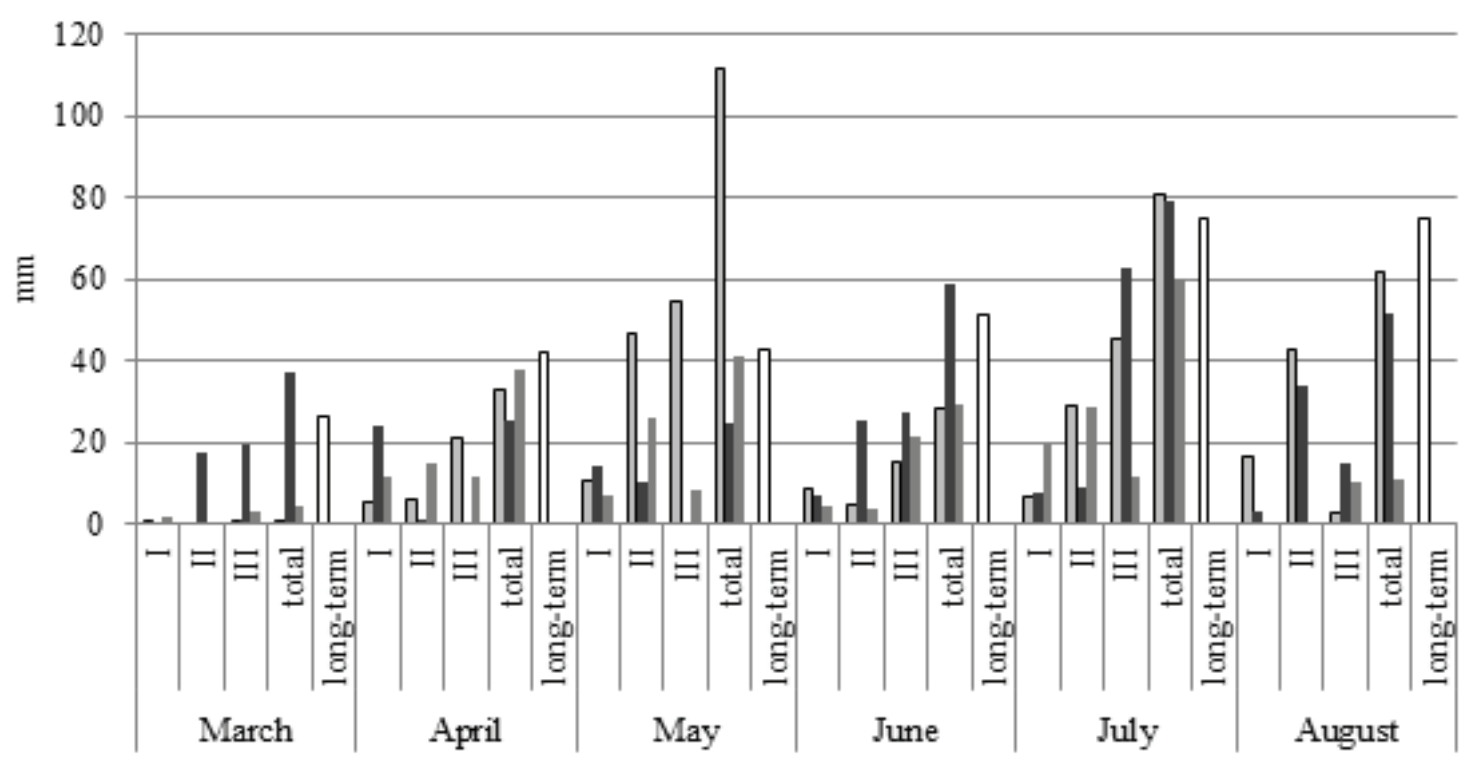

Figure 2. Precipitation sums, Vecauce, 2013-2015 vegetation periods and long term observations, mm, the records of Vecauce meteorological station $(-2013, \mathbf{-}-2014, \square-2015$, I, II, III - ten day period, total monthly, long term monthly).

vegetation started very late - during the $3^{\text {rd }}$ decade of April. In 2014 and 2015, April air temperature was $2.7^{\circ} \mathrm{C}$ and $1.9^{\circ} \mathrm{C}$ above the average for many years, especially in 2014 the $3^{\text {rd }}$ decade when air temperature exceeded the average by $6.7{ }^{\circ} \mathrm{C}$ for many years. In 2013, May air temperature was $3^{\circ} \mathrm{C}$ higher than longterm and rainfall was three times higher than the norm (Figure 2). There was a shortage of air humidity in June when precipitation was lower than long-term mean by 22.6 and $21.6 \mathrm{~mm}$ accordingly in 2013 and 2015. In 2014 and 2015, June air temperature was lower than the norm in the $2^{\text {nd }}$ and $3^{\text {rd }}$ decade. Air temperature in grain filling period - July - was close to the long-term average in 2013 and 2015, but $3{ }^{\circ} \mathrm{C}$ higher than the norm in 2014. In August, precipitation was relatively low if compared with long-term observations and weather was favourable for harvesting in all research years.

\section{Results}

Three - year trial results demonstrated the importance of meteorological condition influence on chlorophyll content changes in winter wheat plant parts. The highest chlorophyll content in winter wheat leaves in 2013 and 2015 was observed at the end of flowering stage reaching 2.91 (N180) and 3.18 (N175+21S) $\mathrm{mg} \mathrm{g}^{-1}$ (Table 2) accordingly. The highest chlorophyll content in 2014 was observed at the beginning of heading stage reaching $3.10 \mathrm{mg}$ $\mathrm{g}^{-1}$ in $\mathrm{N} 175+\mathrm{S} 21$. Differences between years could be explained by the meteorological conditions.
The end of May and the beginning of June in 2014 were characterised by lack of rainfall and high air temperature compared with long term data: air temperature during last ten day period in May exceeded the average by $6.7{ }^{\circ} \mathrm{C}$, plants developed more intensively and sallowed earlier than in other years.

The results of the trial show that chlorophyll content is dependent on the amount of nitrogen and sulphur fertilizer. Depending on the growth stage, chlorophyll content in leaves increased in variants with nitrogen fertilizer to $102 \%$ in 2013 , to $120 \%$ in 2014, and to $117 \%$ in 2015 compared to unfertilized variant. The plant growth stage and nutrition strategy had a significant $(\mathrm{p}<0.05)$ impact on the chlorophyll content in plant leaves in 2013, but the impact of nitrogen fertilizer was not found in 2014 and 2015. The growth stage showed an impact on chlorophyll content in plant leaves in 2015. The growth stage had a factor influence $\left(\eta^{2}\right) 30-70 \%$ on chlorophyll content in leaves but fertilizer application on chlorophyll content $-22-30 \%$ depending on a year.

The chlorophyll content in the wheat stem at the end of flowering was significantly lower than in the terminal leaf - maximum values fluctuated around 1 $\mathrm{mg} \mathrm{g}^{-1}$. The highest chlorophyll content in wheat stems during all years was recorded at the end of flowering in $\mathrm{N} 175+21 \mathrm{~S}$ (from 1.23 to $1.41 \mathrm{mg} \mathrm{g}^{-1}$ ). The variants N150 and N175 were exceptions in 2015, when the chlorophyll content obtained accordingly 0.80 and $0.79 \mathrm{mg} \mathrm{g}^{-1}$. The tendency that chlorophyll content in 
The effect of nitrogen and sulphur fertilizer on winter wheat chlorophyll

Table 2 content, $\mathrm{mg} \mathrm{g}^{-1}$, in the years 2013-2015

\begin{tabular}{|c|c|c|c|c|c|c|c|c|c|c|}
\hline \multirow{3}{*}{$\begin{array}{l}\text { N norm, } \\
\text { kg ha }^{-1}\end{array}$} & \multirow{3}{*}{ Plant fraction } & \multicolumn{3}{|c|}{2013} & \multicolumn{3}{|c|}{2014} & \multicolumn{3}{|c|}{2015} \\
\hline & & \multicolumn{3}{|c|}{ Growth stage BBCH } & \multicolumn{3}{|c|}{ Growth stage BBCH } & \multicolumn{3}{|c|}{ Growth stage BBCH } \\
\hline & & $30-32$ & $49-51$ & $67-69$ & $30-32$ & $49-51$ & $67-69$ & $30-32$ & $49-51$ & $67-69$ \\
\hline \multirow[t]{4}{*}{0} & leaves & 1.36 & 0.76 & 1.51 & 1.99 & 1.91 & 1.34 & 1.52 & 1.29 & 1.47 \\
\hline & stems & 0.41 & 0.06 & 0.38 & 0.40 & 0.62 & 0.52 & 0.22 & 0.07 & 0.34 \\
\hline & ears & - & 0.17 & 0.23 & - & 0.32 & 0.18 & - & 0.05 & 0.24 \\
\hline & whole plant & 1.77 & 1.00 & 2.12 & 2.39 & 2.85 & 2.04 & 1.74 & 1.41 & 2.05 \\
\hline \multirow[t]{4}{*}{85} & leaves & 1.99 & 0.93 & 2.21 & 2.33 & 2.92 & 1.59 & 1.78 & 1.13 & 2.04 \\
\hline & stems & 0.55 & 0.20 & 0.67 & 0.50 & 0.57 & 0.73 & 0.39 & 0.11 & 0.31 \\
\hline & ears & - & 0.18 & 0.28 & - & 0.45 & 0.36 & - & 0.08 & 0.24 \\
\hline & whole plant & 2.54 & 1.31 & 3.16 & 2.83 & 3.94 & 2.68 & 2.17 & 1.32 & 2.60 \\
\hline \multirow[t]{4}{*}{153} & leaves & 1.87 & 0.98 & 2.66 & 1.88 & 3.01 & 2.38 & 1.51 & 2.21 & 1.83 \\
\hline & stems & 0.42 & 0.29 & 0.65 & 0.37 & 0.65 & 0.58 & 0.33 & 0.14 & 0.80 \\
\hline & ears & - & 0.24 & 0.30 & - & 0.40 & 0.48 & - & 0.09 & 0.27 \\
\hline & whole plant & 2.28 & 1.51 & 3.61 & 2.25 & 4.06 & 3.43 & 1.84 & 2.44 & 2.90 \\
\hline \multirow[t]{4}{*}{$175+21 S$} & leaves & 1.78 & 1.39 & 2.68 & 1.85 & 3.10 & 2.08 & 1.44 & 1.58 & 2.78 \\
\hline & stems & 0.56 & 0.25 & 1.23 & 0.50 & 0.85 & 1.41 & 0.29 & 0.13 & 0.79 \\
\hline & ears & - & 0.14 & 0.39 & - & 0.42 & 0.84 & - & 0.09 & 0.30 \\
\hline & whole plant & 2.33 & 1.79 & 4.30 & 2.35 & 4.36 & 4.34 & 1.72 & 1.80 & 3.87 \\
\hline \multirow[t]{4}{*}{175} & leaves & - & - & - & - & - & - & 1.44 & 2.34 & 3.18 \\
\hline & stems & - & - & - & - & - & - & 0.36 & 0.36 & 0.74 \\
\hline & ears & - & - & - & - & - & - & - & 0.14 & 0.45 \\
\hline & whole plant & - & - & - & - & - & - & 1.80 & 2.84 & 4.37 \\
\hline \multirow[t]{4}{*}{187} & leaves & 2.00 & 1.55 & 2.64 & 2.20 & 2.10 & 2.95 & 1.32 & 1.59 & 2.01 \\
\hline & stems & 0.42 & 0.22 & 0.70 & 0.60 & 0.88 & 0.98 & 0.36 & 0.18 & 0.59 \\
\hline & ears & - & 0.31 & 0.21 & - & 0.66 & 0.61 & - & 0.11 & 0.31 \\
\hline & whole plant & 2.42 & 2.07 & 3.55 & 2.80 & 3.64 & 4.54 & 1.69 & 1.88 & 2.90 \\
\hline \\
\hline $\begin{array}{r}150 \\
(2014)\end{array}$ & stems & 0.78 & 0.45 & 0.98 & 0.41 & 0.93 & 0.81 & 0.32 & 0.06 & 0.50 \\
\hline \multirow[t]{2}{*}{$\begin{array}{r}205 \\
(2015)\end{array}$} & ears & - & 0.21 & 0.52 & - & 0.43 & 0.71 & - & 0.05 & 0.28 \\
\hline & whole plant & 2.61 & 2.02 & 4.41 & 2.01 & 4.23 & 4.07 & 1.79 & 1.35 & 3.57 \\
\hline \multirow[t]{3}{*}{$\operatorname{LSD}_{0.05}$} & leaves & & 0.42 & & & 0.81 & & & 0.78 & \\
\hline & stems & & 0.25 & & & 0.30 & & & 0.21 & \\
\hline & ears & & 0.27 & & & 0.37 & & & 0.08 & \\
\hline
\end{tabular}

plant stems increases with higher nitrogen and sulphur fertilizer levels was noted for all years. According to the F-test, the plant growth stage had a significant impact $(\mathrm{p}<0.05)$ on the plant stem chlorophyll content in all years. The wheat additional fertilization with nitrogen and sulphur fertilizer significantly $(p<0.05)$ increased chlorophyll content in stems only in 2013.
The growth stage had factor influence $\left(\eta^{2}\right) 40-66 \%$ on chlorophyll content in stems but fertilizer application on chlorophyll content $-17-36 \%$ depending on a year.

The chlorophyll content in the ear was very low in relation to the terminal leaf and stem and did not exceed $0.84 \mathrm{mg} \mathrm{g}^{-1}$ (in 2014). The highest chlorophyll 
Table 3

Correlation between winter wheat chlorophyll content and nitrogen concentration and grain yield, in the years 2013-2015

\begin{tabular}{|c|c|c|c|c|c|c|c|c|c|}
\hline \multirow{3}{*}{ Parameter } & \multicolumn{9}{|c|}{ Year, plant growth stage } \\
\hline & \multicolumn{3}{|c|}{2013} & \multicolumn{3}{|c|}{2014} & \multicolumn{3}{|c|}{2015} \\
\hline & $\begin{array}{l}\mathrm{BBCH} \\
30-32\end{array}$ & $\begin{array}{l}\mathrm{BBCH} \\
49-51\end{array}$ & $\begin{array}{l}\mathrm{BBCH} \\
67-69\end{array}$ & $\begin{array}{l}\mathrm{BBCH} \\
30-32\end{array}$ & $\begin{array}{l}\mathrm{BBCH} \\
49-51\end{array}$ & $\begin{array}{l}\mathrm{BBCH} \\
67-69\end{array}$ & $\begin{array}{l}\mathrm{BBCH} \\
30-32\end{array}$ & $\begin{array}{l}\mathrm{BBCH} \\
49-51\end{array}$ & $\begin{array}{l}\mathrm{BBCH} \\
67-69\end{array}$ \\
\hline $\begin{array}{l}\text { Chlorophyll } \\
\text { content vs } \\
\text { nitrogen } \\
\text { concentration }\end{array}$ & $0.90 *$ & 0.78 & $0.92 * *$ & -0.03 & $0.90^{*}$ & $0.98 * *$ & 0.17 & 0.67 & $0.79 *$ \\
\hline $\begin{array}{l}\text { Chlorophyll } \\
\text { content vs grain } \\
\text { yield at BBCH } \\
88-92\end{array}$ & $0.85^{*}$ & $0.83^{*}$ & $0.87^{*}$ & -0.20 & 0.67 & $0.97 * *$ & -0.13 & 0.70 & $0.95^{* *}$ \\
\hline
\end{tabular}

*Significant at the 0.05 probability level

**Significant at the 0.01 probability level

content in ears at the end of flowering in 2014 and 2015 was observed in N175+S21, in 180 (test) during the year 2013 when portable chlorophyll meter was used to determine needed nitrogen fertilizer. At the end of flowering stage the chlorophyll content varied between $0.21-0.52$ according to the nitrogen nutrition in 2013, in 2014 it varied from 0.18-0.84, and in 2015 - from $0.24-0.45 \mathrm{mg} \mathrm{g}^{-1}$. The plant growth stage had a significant impact $(\mathrm{p}<0.05)$ on chlorophyll content in ears only in 2015, while nitrogen fertilization had no significant effect on chlorophyll content.

Data about grain yield and nitrogen concentration, described in details in the paper by Skudra \& Ruza, 2015, was used to determine chlorophyll content and grain yield and nitrogen concentration correlation. Wheat yields were caused by meteorological conditions and fertilizer management and it varied from 4.07 to $7.84 \mathrm{t} \mathrm{ha}^{-1}$ in $2013,2.79-5.20 \mathrm{t} \mathrm{ha}^{-1}$ in 2014 and $4.23-10.20 \mathrm{t} \mathrm{ha}^{-1}$ in 2015 . The average nitrogen concentration during a three-year period in wheat plant according to different growth stages $(\mathrm{BBCH})$ was $7.56 \%$ at $\mathrm{BBCH} 32,6.33 \%$ at $\mathrm{BBCH}$ 51 and $5.55 \%$ at $\mathrm{BBCH}$ 69. Detailed data analysis is described in our previous paper (Skudra \& Ruza, 2015).

Close positive correlations were observed between grain yields and wheat plant chlorophyll content and nitrogen concentration at the end of flowering stage in all years. These correlations indicated that the application of extra nitrogen influences wheat chlorophyll content (Table 3). The chlorophyll content correlated with nitrogen concentration at stem elongation stage in 2013 and at the beginning of heading in 2014. The plant growth stage and nutrition strategy had a significant impact on the nitrogen concentration in plant leaves and stems $(\mathrm{p}<0.05)$ (Skudra \& Ruza, 2015). The positive correlation between grain yield and chlorophyll plant content depending on nitrogen and sulphur fertilization levels was observed at the stem elongation and beginning of heading stage in 2013 at the 95\% probability level.

\section{Discussion}

Plant growth depends on photosynthesis, which is influenced by environmental conditions such as temperature and nutrition (Janušauskaite, Auškalniene, \& Pšibišauskiene, 2016, Stramkale et.al, 2008). The chlorophyll content is one of the parameters of photosynthetic activity and it is particularly significant in precision agriculture. The ratio of chlorophyll content is a suitable senescence indicator (Tranavičiene et al., 2008) and depends on a year (Priadkina et al., 2014). Leaf chlorophyll content is an informative parameter for the estimation of the nitrogen uptake from the soil under different growth conditions. Study results show that methods as determination of chlorophyll content in leaves and determination of changes in chlorophyll amount in leaves are enough to assess the yield in a definite growing season. Usage of photometric methods during wheat growing season gives the opportunity to determine needed fertilizer in order to affect yield formation process in a desirable direction and can help with the prognosis of possible yield and its quality (Dromantiene, Pranckietiene, \& Šidlauskas, 2015). 
Chlorophyll content changes in winter wheat leaves identified in the present study were mainly similar to the results described in the literature. Researchers from Serbia Bojovič and Stojanovič (2005) reported that the greatest chlorophyll content in winter wheat plants occurs at the end of flowering stage, where the greatest chlorophyll content (from 2,4 to $3,2 \mathrm{mg} \mathrm{g}^{-1}$ depending on variety) was measured on the soil fertilized with nitrogen $\left(150 \mathrm{~kg} \mathrm{ha}^{-1}\right)$ and phosphorus $\left(80 \mathrm{~kg} \mathrm{ha}^{-1}\right)$, but chlorophyll content in the uppermost part of the stem at the outset flowering is significantly lower than in the wheat leaves (around $\left.1 \mathrm{mg} \mathrm{g}^{-1}\right)$.

According to our investigations, the mineral fertilizers increased the amount of chlorophyll content in all plant parts. Nitrogen fertilizer with sulphur $(\mathrm{N} 175+\mathrm{S} 21)$ helps to achieve the highest chlorophyll content in leaves, stems and ears in two years. Scientists Selim and Mahmoud (2015) conclude that additional sulphur fertilizer plays a positive role for improving nitrogen uptake in wheat grains. Study in Estonia (Jarvan et al., 2012) indicated that the application of sulphur containing fertilizers on break-stony soil increased grain yield (21\%) and protein content.

Many authors (Silva et al., 2014, Theago et al., 2014, Priadkina et al., 2014) have established that chlorophyll photosynthetic potential, characterizing the total amount of chlorophyll in the aboveground plant parts during the vegetative period under optimal environmental and climatic conditions correlated with the yield. In the present study, there was found a close correlation between chlorophyll content and grain yield at the end of flowering stage, but not in stem elongation and beginning of heading stage (except in 2013). Researcher Spanic et al. (2013) found that the grain yield of winter wheat does not depend on photosynthesis in optimal conditions, but on other physiological process which may be related to the energy usage efficiency or assimilate mobilization.

This study shows close positive correlation in all years between the wheat plant chlorophyll content and nitrogen concentration at the end of flowering stage. Many researchers (Shadcina \& Dmitrieva, 1995, Janušauskaite \& Feiziene, 2012, Theago et al., 2014) found close correlation between chlorophyll content in the leaves and the total nitrogen concentration in the plants, which is independent of the conditions of the growth of the plants. It is explained by nitrogen, which is a structural element of chlorophyll and protein molecules and has an impact on formation of chloroplasts and chlorophyll accumulation in them (Bojovič \& Markovič, 2009).

\section{Conclusions}

1. Chlorophyll content in different plant parts depends on the usage of nitrogen and sulphur fertilizer. Additional sulphur fertilizer provided chlorophyll content maximum in leaves, stems and ears in two trial years, but chlorophyll meter usage - in one trial year.

2. Plant growth stage had a significant $(\mathrm{p}<0.05)$ impact on chlorophyll content in stems in all trial years, in leaves in two trial years, and in ears during one trial year.

3. Nitrogen fertilization had a significant effect $(p<0.05)$ on chlorophyll content in leaves and stems in only one trial year.

4. Close positive correlation was observed between the grain yields and wheat plant chlorophyll content and nitrogen concentration at the end of the flowering stage in all trial years.

\section{References}

1. Akhter, M.M., Hosain, A., Timsina, J., Teixeira da Silva, A., \& Islam, M.S. (2016). Chlorophyll meter - a decision-making toll for nitrogen application in wheat under light soils. International Journal of Plant Production 10 (3), 289-302. DOI: 10.22069/ijpp.2016.2898.

2. Bojovič, B. \& Markivič, A. (2009). Correlation between nitrogen and chlorophyll content in wheat (Triticum aestivum L.). Kragujevac Journal of Science, 31, 69-74.

3. Bojovič, B \& Stojanovič, J. (2005). Chlorophyll and carotenoid content in wheat cultivars as a function of mineral nutrition. Archives of Biological Sciences, 57 (4), 283-290.

4. Castelli, F., Contillo, R., \& Miceli, F. (1996). Non-destructive determination of leaf chlorophyll content in four crop species. Journal of Agronomy and Crop Science, 177 (4), 275-285. DOI: 10.1111/j.1439-037X.1996. tb00246.x.

5. Dromantiene, R., Pranckietiene, I., \& Šidlauskas, G. (2015). Effect of foliar application of amino acids on the photosynthetic indicators and yield of winter wheat. In Proceedings of the $7^{\text {th }}$ International Scientific Conference Rural Development 2015, 19-20 November 2015 (pp. 1-8) Kaunas, Lithuania: Aleksandras Stulginskis University.

6. Foxa, R. H., Piekieleka, W. P. \& Macneala, K. M. (1994). Using a chlorophyll meter to predict nitrogen fertilizer needs of winter wheat. Communications in Soil Science and Plant Analysis 25 (3-4), 171-181, DOI: 10.1080/00103629409369027. 
7. Inada, K. (1963). Studies on a method for determining the deepness of green color and chlorophyll content of intact crop leaves and its practical applications. I. Principles for estimating the deepness of green color and chlorophyll content of whole leaves. Japanese Journal of Crop Science, 32 (2), 157-162, DOI: 10.1626/ jcs.32.157.

8. Janušauskaite, D., Auškalniene, O. \& Pšibišauskiene, G. (2016). Photosynthetic responses of spring barley varieties to different stand densities under field conditions. Acta Agriculturae Scandinavica Section B - Soil and Plant Science, 62:5, 441-448, DOI: 10.1080/09064710.2011.641029.

9. Janušauskaite, D., \& Feiziene, D. (2012). Chlorophyll fluorescence characteristics throughout spring triticale development stages as affected by fertilization. Acta Agriculturae Scandinavica Section B - Soil and Plant Science, 62, 7-15, DOI: 10.1080/09064710.2011.560122.

10. Jarvan, M., Edesi, L. \& Adamson A. (2012). The content and quality of protein in winter wheat grains depending on sulphur fertilization. Acta Agriculturae Scandinavica Section B Soil and Plant Science, 62, 627-636, DOI: 10.1080/09064710.2012.683495.

11. Karele, I. (2001). Chlorophyll content distribution in leaves, stems, and ears. In W.J. Horst, M.K. Schenk, A. Burkert, N. Claassen, H. Flessa, W.B. Frommer, L. Wittenmayer (Eds.), Plant Nutrition: Food security and sustainability of agro-ecosystems through basic and applied research. (pp.720-721). The Netherlands: Kluwer Academic Publishers.

12. Kulhanek, M., Balik, J., Černy, J, Peklova, L., \& Sedlar, O. (2014). Winter wheat fertilizing using nitrogen - sulphur fertilizer. Archives of Agronomy and Soil Science 60 (1), 67-74, DOI: 10.1080/03650340.2013.771260.

13. Marinkina, G.A., Marx E.I. (2014). The effect of fertilizers and herbicides on chlorophyll accumulation, photosynthesis productivity and wheat yeild. [Abstract] Bulletin of NSAU (Novosibirsk State Agrarian University), 3(32), 37-41.

14. Priadkina, G.A., Stasik O.O., Mikhalskaya, L.N., \& Shvartau, V.V. (2014). A relationship between chlorophyll photosynthetic potential and yield of winter wheat (Triticum aestivum L.) at elevated temperatures. Sel'skokhozyaistvennaya biologiya (Agricultural biology), 5, 88-95, DOI: 10.15389/ agrobiology.2014.5.88eng.

15. Richardson, A.D., Duigan, S.P., \& Berlyn, G.P. (2002). An evaluation of noninvasive methods to estimate foliar chlorophyll content. New Phytologist, 153 (1), 185-194, DOI: 10.1046/j.0028-646X.2001.00289.x.

16. Salvagiotti, F., Castellarin, J.M., Miralles, D.J., \& Pedrol, H.M. (2009). Sulfur fertilization improves nitrogen use efficiency in wheat by increasing nitrogen uptake. Field Crops Research, 113, 170-177. DOI: 10.1016/j. fcr.2009.05.003.

17. Shadchina, T.M. \& Dmitrieva, V.V. (1995). Leaf chlorophyll content as a possible diagnostic mean for the evaluation of plant nitrogen uptake from the soil. Journal of Plant Nutrition, 18 (7), 1427-1437. DOI: http://dx.doi. org/10.1080/01904169509364992.

18. Schlichting, A.F., Bonfim-Silva, E.M., Silva, de C.M., Pietro-Souza, W., Silva, da T.J.A., \& Farias, L. do N. (2015). Efficiency of portable chlorophyll meters in assessing the nutritional status of wheat plants. Revista Brasileira de Engenharia Agricola e Ambiental 19(12), 11481151. DOI: http//dx.doi.org/10.1590/1807-1929/ agriambi.v19n12p1148-1151.

19. Selim, A.K., \& Mahmoud S. (2015). Effect of sulfur and stabilized ammonium nutrition on nutrient uptake by wheat in clay and calcareous soils. Agriculture \& Forestry / Poljoprivreda i Sumarstvo. 61 (1), 121-125. Podgorica, Montenegro, DOI: 10.17707/ AgricultForest.61.1.15.

20. Silva, da C.L., Benin, G., Bornhofen, E., Beche, E., Todeschini, M.H. \& Milioli, A.S. (2014). Nitrogen use efficiency is associated with chlorophyll content in Brazilian spring wheat [Abstract]. Australian Journal of Crop Science, 8 (6), 957-964. Retrieved August 26, 2016, from https://search.informit.com.au/documentSumma ry; $\mathrm{dn}=480405081584778 ;$ res=IELHSS.

21. Skudra, I. \& Ruža, A. (2015). Nitrogen Content Changes in Winter Wheat (Triticum Aestivum L.) Depending on Fertilizer norms. In Nordic View to Sustainable Rural Development: Proceedings of the 25th NJF Congress, 16-18 June 2015 (pp. 170-174). Riga, Latvia, Nordic Association of Agricultural Scientists.

22. Spanic, V., Viljevac, M., Drezner, G. \& Lepedu's, H. (2013). Chlorophyll fluorescence parameters and grain yield of winter wheat genotypes. In 48 . Hrvatski I 8. Meunarodni Simpozij Agronoma, 17-22 veljač 2013 (pp. 323-327). Dubrovnik, Hrvatska: Radova Osijeku.

23. Stramkale, V., Stramkalis, A., Pakarna, G. \& Vikmane, G. (2008). Fotosintēzes pigmentu satura izmainas vasaras kviešu lapās atkarīīā no minerālelementu piegādes caur lapām. (The 
content of photosynthetic pigments in spring wheat leaves in dependence on mineral supply through leaves) Agronomijas Vēstis, Nr.10, 299308. pp. (in Latvian).

24. Theago, E.Q., Buzetti, S., Teixeira, M.C.M., Andreotti, M., Megda, M.M. \& Benett, C.G.S. (2014). Nitrogen application rates, sources, and times affecting chlorophyll content and wheat yield. [Abstract]. Revista Brasileira de Ciencia do Solo, 38(6), 1826-1835 (in Portuguese).

25. Tranavičiene, T., Urbonavičiūte, A., Samouliene, G., Duchovskis, P., Vagusevičiene, I. \& Sliesaravičius, A. (2008). The effect of differential nitrogen fertilization on photosynthetic pigment and carbohydrate content in the two winter wheat varieties. Agronomy Research 6(2), 555-561.

26. Živčak, M., Olšovska, K., Slamka, P., Galambošova, J., Rataj, V., Shao, H., Kalaji, H.M. \& Brestič, M. (2014). Measurements of chlorophyll fluorescence in different leaf positions may detect nitrogen deficiency in wheat. Zemdirbyste-Agriculture. 101 (4), 437444. DOI: 10.13080/z-a.2014.101.056.

27. Wellburn, A.R. (1994). The spectral determination of chlorophylls a and $\mathrm{b}$, as well as total carotenoids, using various solvents with spectrophotometers of different resolution. Journal of Plant Physiology. 144, 307-313. 